\title{
Investigating the Direct and Indirect Effects of Corporate Hypocrisy and Perceived Corporate Reputation On Consumers' Attitudes Toward the Company
}

\begin{abstract}
Consumers are placing increasing importance on the social responsibility of firms when making purchase decisions. Nonetheless, corporate irresponsibility has become more prevalent in the corporate world. Through corporate social responsibility (CSR), companies can showcase their virtues and appear as good citizens while ignoring many internal standards. Hence, the primary purpose of this study was to explore the impact of corporate hypocrisy on CSR belief, corporate reputation, and consumers' attitudes toward a company that may have a bad reputation. Second, we investigated the mediating effect of CSR belief and perceived corporate reputation on the relationships between corporate hypocrisy and consumers' attitudes toward the company. We asked a sample of respondents in Australia (n $=518$ ) to respond to a real CSR campaign launched by a beer company. The results showed that CSR belief mediates the relationship between corporate hypocrisy and consumers' attitudes toward the company. The results indicated a perception that companies may use CSR to try to shift the blame from producers to users. The results of this study provide guidelines for managers, social marketers, and public policy makers on how to create and evaluate companies' CSR campaigns. The results of this study contribute to the debate on how consumers respond to various CSR campaigns as well as the intended or unintended consequences of CSR in directing consumers' attention away from the negative impacts businesses have on society.
\end{abstract}

Keywords Corporate Social Responsibility, Corporate Hypocrisy, Corporate Reputation Paper type Research paper 


\section{Introduction}

Consumers are placing increasing importance on the social responsibility of companies when making purchase decisions (Wagner, Lutz, \& Weitz, 2009; Wan, Poon, \& Yu, 2016). Luo and Bhattarcharya (2006) found that consumers’ perceptions of corporate social responsibility (CSR) influence how they perceive brands, affect intentions to purchase and patronize the retailer, and affect the financial performance of firms. In recent years, one of the main social issues has been excessive alcohol consumption (Kubacki, Siemieniako, \& Rundle-Thiele, 2011). Research has shown that alcohol use is a significant risk factor for various health problems (Room, Babor, \& Rehm, 2005; Rundle-Thiele, Russell-Bennett, Leo, \& Dietrich, 2013; Wechsler, Lee, Kuo, \& Lee, 2000). Hence, Jones, Hillier, and Comfort (2013) found that the leading beer companies are moving toward integrating CSR into their core businesses with responsible drinking at the forefront of their CSR agendas. Nonetheless, corporate irresponsibility has become more prevalent in the corporate world.

A damaged reputation can significantly impact a company’s profits and sales (Vanhamme \& Groben, 2009). Consumers have become more negative toward the CSR activities companies have launched, especially in an industry such as beer and spirits (Illia, Zyglidopoulos, Romenti, Rodríguez-Cánovas, \& del Valle Brena, 2013; Jones et al., 2013; Skarmeas \& Leonidou, 2013). Szykman, Bloom, and Blazing (2004) found that consumers who viewed an anti-drinking and driving message saw it as more self-serving when a beer company sponsored it. However, despite the controversy and bad reputations (Yoon, Gürhan-Canli, \& Schwarz, 2006), through CSR, beer companies can showcase their virtues and can appear as good citizens while ignoring many internal standards (Jones, Bowd, \& Tench, 2009; Jones et al., 2013; Yoon \& Lam, 2013). In the context of the beer industry, government has also identified that the type of beer brewers produce can play a significant role in reducing alcohol problems (Baggot, 2006). These dilemmas create conflicts between 
the public images of companies and how consumers respond to various CSR campaigns the companies launch to portray themselves as good citizens.

Hence, the primary purpose of this study was to explore the impact of corporate hypocrisy on CSR belief, corporate reputation, and consumers' attitudes toward a beer company. Second, we investigated the mediating effect of CSR belief and perceived corporate reputation on the relationships between corporate hypocrisy and consumers' attitudes toward the company. The results of this study contribute to the debate on how consumers respond to various CSR campaigns as well as the intended or unintended consequences of CSR in directing consumers' attention away from the negative impacts businesses have on society. Subsequently, the results of this study provide guidelines for managers and public policy makers on how to manage and evaluate CSR campaigns.

\section{Literature Review and Hypothesis Development}

\subsection{Corporate Social Responsibility}

Carroll (1991, p. 43) defined CSR as “the simultaneous fulfillment of the firm’s economic, legal, ethical and philanthropic responsibilities.... CSR firms should strive to make a profit, obey the law, be ethical, and be ... good corporate citizen[s].” Similarly, Maignan, Ferrell, and Hult (1999) defined CSR as the extent to which organizations meet the legal, economic, ethical, and discretionary responsibilities that relevant stakeholders require.

CSR has influenced various elements of businesses such as the impact of CSR behavior on the greater community (Albinger \& Freeman, 2000; Arli \& Cadeaux, 2014; Oppewal, Alexander, \& Sullivan, 2006; Sen \& Bhattacharya, 2001), the juxtaposition of CSR and the management of the multiple interests of multiple stakeholders (Matten, Crane, \& Chapple, 2003; Waddock, 2004), the price consumers are willing to pay for CSR (Creyer \& Ross, 1996; Karem, Abou, \& El-Bassiouny, 2012; Parsa, Kenneth, Putrevu \& Kreeger, 2015, 
2015), discussion of CSR in the context of consumer loyalty (Bhattacharya \& Sen, 2003;

Lichtenstein, Drumwright, \& Braig, 2004), reconceptualization of the store image (Gupta \& Pirsch, 2008); the influence of CSR on financial performance (Orlitzky, 2003), and the effect of hypocrisy and inconsistent CSR messages on consumer purchase decisions (Wagner et al., 2009). These studies reveal the many areas within the CSR domain that have received academic attention.

One area of particular interest in this research is how consumers respond to bad corporate behavior. Prior research has revealed nine ways consumers respond to perceived corporate misfeasance: through boycott (Klein, 2004), outrage (Lindenmeier, Schleer, \& Pricl, 2012), cynicism (Chylinski \& Chu, 2010), distrust (Darke \& Ritchie, 2007), perceptions of corporate hypocrisy (Wagner et al., 2009), hatred (Lee, 2009), apathy (Devinney, 2006), or revenge (Sweetin, Knowles, Summey, \& McQueen, 2013). Of these, this research has specifically explored the effects of corporate hypocrisy on the overall feelings consumers have toward companies in response to CSR campaigns.

\subsection{Hypothesis Development}

\subsubsection{Corporate Hypocrisy}

Corporate hypocrisy is a stakeholder's belief that a firm has failed to deliver on its promises (Wagner et al., 2009). Corporations may communicate their good behavior (promises) to their stakeholders, but when consumers find a discrepancy between their claims and their actions, they risk accusations of hypocrisy. According to Szabados (2004), many understand hypocrisy as a subtle type of deception. This type of deceptive behavior undermines stakeholder trust, threatening the very relationships that helped to create the corporation (for example, those with investors) and those that continue to sustain the corporation (for 
example, those with consumers and employees). Yoon et al. (2006) found that CSR activities are ineffective when the sincerity of a firm is ambiguous.

CSR activities can improve a company’s image only when consumers believe those activities have a sincere motive (Yoon et al., 2006). Furthermore, a seminal study by Wagner et al. (2009) focused on the impact of communication strategies on consumer perceptions of corporate hypocrisy. Wagner et al. found that proactive communication (actively positioning themselves as engaging and supporting CSR strategies before acting) had a greater influence on corporate hypocrisy than reactive communication (what said the firm said after the incident). Furthermore, they found that regardless of the type of communication strategy, or the order in which the company presents information to consumers, information inconsistency ultimately leads to perceptions of corporate hypocrisy. Corporate hypocrisy has a destructive impact on a consumer's overall attitude toward the corporation when there is a bifurcation between promises and actions, showcasing that "all is not well with the corporate world” (Crowther \& Rayman-Bacchus, 2004, p. 1). Hence, we suggest the following hypotheses:

H1: Corporate hypocrisy negatively influences CSR beliefs of consumers about the company.

H2: Corporate hypocrisy negatively influences the perceived corporate reputation of the company among consumers.

H3: Corporate hypocrisy negatively influences consumers' attitudes toward the company.

\subsubsection{CSR Belief}

CSR belief refers to beliefs by consumers that a company is acting as a responsible entity in society or the extent to which consumers believe a company is socially responsible (Du, Bhattacharya, \& Sen, 2007). Dating as far back as the work of Friedman (1970), this topic 
has undergone extensive debate as to whether a corporation has an obligation to the society in which it operates. On the one hand, some believe that every large corporation should act as a social enterprise (Dahl, 1972; Murray \& Vogel, 1997) as far as it serves the public. On the other hand, some consider the responsibility of a corporation to make decisions that purely maximize the value for stakeholders, with society as just one of those many stakeholders. In essence, a corporation cannot maximize its equity if it ignores the interest of its stakeholders (Jensen, 2001); yet, for some corporations, the welfare of society is not a priority.

H4: Consumers' CSR beliefs positively influence consumers' attitudes toward the company.

\subsubsection{Perceived Corporate Reputation}

Fombrun (1996, p. 72) defined corporate reputation as “a perceptual representation of a company’s past actions and future prospects that describe the firm's overall appeal to all its key constituents when compared to other leading rivals.” Roberts and Dowling (2002) found support for the connection between firm financial performance and the presence of intangible assets - such as reputation. High-quality intangible assets do have an influence on superior performance. For example, the Body Shop, founded in 1976, has incorporated its in-house public relations department within a larger unit labeled values and vision. This ensures that those responsible for creating the public persona align with the overarching CSR objectives (Quarter, 2000). The success of the Body Shop in marketing itself as a socially responsible company is one example of the influence corporate reputation can have on overall performance (Argenti \& Druckenmiller, 2004; Fombrun, 1996; McIntosh, 2015). Therefore, we propose the following hypothesis:

H5: Consumers' perceptions of a company's corporate reputation positively influence consumers' attitudes toward the company. 


\subsubsection{Mediating Variables}

Stanaland, Lwin \& Murphy (2011) examined consumer perceptions of CSR and found that particular cues (such as high-quality ethics statements from the corporation) influenced perceived CSR, which in turn impacted consumer trust and loyalty. In another study, Valentine \& Fleischman (2008) empirically examined employees’ perceptions of CSR and how those perceptions influenced job satisfaction. Furthermore, they found that support for perceived CSR played a mediating role in the relationship between ethics programs and job satisfaction, indicating the importance of CSR initiatives (Deshpande, 1996) for creating and sustaining positive perceived CSR. Hence, we propose the following hypotheses:

H6: Consumers' CSR beliefs mediate the relationship between corporate hypocrisy and consumers' attitudes toward the company.

Studies have found that corporate reputation often mediates the relationship between the company and consumers' attitude toward the company (Boulstridge \& Carrigan, 2000; Hur \& Woo, 2014; Lii \& Lee, 2012; Nguyen \& Leblanc, 2001). Corporate reputation can act as a reflection of a firm's history, which influences the believability of the firm (Herbig \& Milewicz, 1993; Yoon \& Lam, 1993). It is a process that accumulates the judgements over time of various stakeholders who interact with the firm (Nguyen \& Leblanc, 2001). Hence, company reputation may reduce the impact of inconsistent messages of the company. Therefore, we propose the following hypotheses:

H7: Consumers' perceptions of corporate reputation mediate the relationship between consumers' perceptions of corporate hypocrisy and consumers' attitudes toward the company.

\subsubsection{Dependent Variable - Overall Attitude Toward the Firm}

The consumer is an extremely influential stakeholder group, thereby often giving firms strong reason for engaging in CSR activities as a type of “window dressing” (Fatma \& Rahman, p. 
196). It is another expense necessary to conduct business in today's climate (Sprinkle \& Maines, 2010), and consumers dictate the extent of this behavior through their purchase decisions (Luo \& Bhattacharya, 2006). Consumer satisfaction and loyalty are essential for the longevity of any large corporation (Hallowell, 1996). Wagner et al. (2009) found that perceptions of hypocrisy damaged consumers' overall attitudes toward firms. Furthermore, Becker-Olsen et al. (2006) found that consumers' overall feelings toward firms are multifaceted: (a) consumers react differently to different corporate marketing campaigns based on fit (does the CSR message link with the firm’s brand, product line, target market); (b) motivation (underlying selfish motives or altruistic motives); and (c) timing (proactive versus reactive). Overall, the major finding was that low-fit communication strategies have a strong, negative impact on consumer attitudes.

In summary, Figure 1 shows the conceptual framework for this research, illustrating how CSR belief and corporate reputation mediate the relationship between corporate hypocrisy and consumers' attitudes toward the company. Many studies have demonstrated how CSR behavior influences customers (Arli \& Lasmono, 2010; Brown \& Dacin, 1997; Klein \& Dawar, 2004; Mohr \& Webb, 2005; Wagner et al., 2009). We tested consumers' responses toward one of Anheuser-Busch’s CSR campaigns. Hence, the hypotheses predicted results based on this campaign. The conceptual model has practical relevance in the marketplace because the outcome variable (overall attitude toward the firm) has previously played an influential role in consumer purchase decisions (Pan \& Zinkhan, 2006). Insert Figure 1 About Here

\section{Methodology}

\subsection{Design}

We employed a cross sectional design in which we exposed participants to a CSR banner campaign by Anheuser-Busch (see Figure 2). As one of the best-selling beer companies, the 
company launched a CSR campaign to raise awareness about preventing drunk driving. After showing the CSR banner campaign, we asked participants a series of questions so that we could rate their perceptions of the company’s CSR practices based on the banner campaign. We designed the questions to test our hypotheses and to determine whether the independent variables (a) corporate hypocrisy, (b) CSR belief, and (c) perceived corporate reputation in our conceptual model can measure and/or predict consumers' attitudes toward a company as well as exploring for potential mediation effects.

\subsection{Data Collection}

There were 518 Australian respondents (49.9\% male; 53.9\% single; 42.7\% with high-school education) residing within the city of Brisbane, Queensland (see Table 1). We utilized a paper-based survey to collect responses from participants. We distributed surveys to students from a large Australian public university and their families and friends. We recruited participants during the month of April 2016. We analyzed the data using SEM (IBM AMOS 23).

\section{Insert Table 1 About Here}

\subsection{Measures}

All the measures used seven-point Likert-type scales with anchors ranging from 1 (strongly disagree) to 7 (strongly agree). We adapted the scales from previous research. We adapted CSR belief from Maignan (2001) and Crespo and del Bosque (2005) (e.g., ... is a socially responsible company); perceived corporate reputation from Brown (1995) and Ganesan (1994) (e.g., the company has a reputation of being honest); corporate hypocrisy from Wagner et al. (2009) (e.g., What ... says and does are two different things). Finally, we adapted attitude toward the company from Homer (1995) (e.g., $1=$ Unfavorable; $5=$ Favorable). Table 2 summarizes the scale items we used in this study 


\section{Insert Table 2 About Here}

\subsection{Reliability}

Using structural equation modelling (AMOS), we ran a confirmatory factor analysis on the measures. The fit of the model was good for $\left(x^{2}(d f)=205.244(71)\right.$; CFI $=.97$; TLI $=0.96$; NNFI $=.96 ;$ RMSEA $=.06 ;$ SRMR $=.04)$. The fit of the models was well above the recommended values (Joreskor \& Sorbom, 1993; Steiger, 1990).

We calculated Cronbach’s alpha for each key variable to test for internal consistency reliability. We assessed convergent validity by determining whether factor loadings were greater than .50 and statistically significant $(\mathrm{p} \leq .05)$. The minimum factor loading was 0.67 (Bagozzi \& Yi, 2012). Values below the threshold of .60 indicate unsatisfactory internal consistency (Malhotra \& Birks, 2007). Confidence intervals around the correlation estimates between any two constructs were all significantly different from one (Anderson \& Gerbing, 1988). To assess discriminant validity among the constructs, we compared the average variance extracted (AVE) values for each construct with the squared correlation estimates of paired measured constructs in the model (Fornell \& Larcker, 1981). The AVE ranged from 0.59 to a maximum of 0.80 . We calculated composite reliability values (CR) and compared them to a threshold benchmark of .60 (Bagozzi \& Yi, 1988). The minimum CR for this study ranged from 0.85 to 0.94 . We tested the variance and found that the AVE for each factor was higher than the square of the correlation coefficient with each of the other factors (see Table 3). Thus, the test confirmed the measurement model discriminant validity (Fornell \& Larcker, 1981).

Insert Table 3 About Here

\subsection{Mediation Analysis}

To test for mediation effects, we conducted a separate bias-corrected bootstrap analyses with the mediator (corporate hypocrisy) using a series of multiple regression analyses (Preacher, 
2004, 2008; Zhao, Lynch, \& Chen, 2010). A bootstrap test resamples the data to estimate standard errors and to derive a confidence interval with the bootstrapped sampling distribution. The bias-corrected confidence interval is useful as it considers non-normal distributions of mediation effects and produces more accurate Type 1 error rates (Lau \& Cheung, 2010). Meaningful mediating effects can occur without a significant direct relationship between independent and dependent variables (Zhao et al., 2010). Thus, the test only determined direct effects between the mediator and independent variable and between the mediator and dependent variable prior to assessment of mediation. A mediating effect is significant if the 95\% confidence intervals do not bracket zero. Finally, Baron and Kenny (1986) suggested three necessary conditions to claim the mediating effect: (a) there is a significant relationship between X (independent variable) and M (mediating variable), (b) there is a significant relationship between $\mathrm{M}$ and $\mathrm{Y}$ (dependent variable), and (c) the relationship between $\mathrm{X}$ and $\mathrm{Y}$ diminishes when $\mathrm{M}$ in is the model. Hence, based on the previous criteria, we tested for statistically significant results for mediation of the relationship between the CSR belief, CSR reputation, and consumers' attitudes toward the company by corporate hypocrisy.

\section{Results}

\subsection{Direct Effect}

Having established the unidimensionality and reliability of the models, in the next step we estimated the hypothesized relationships between the constructs of this study. Overall, the findings we presented in Figure 2 and Table 4 suggested that the hypothesized structure model fitted the data well for the beer company: $x^{2} / \mathrm{df}(71)=205.244, p=0.00$; NFI = .96; $\mathrm{TLI}=.96 ; \mathrm{CFI}=.97 ; \mathrm{SRMR}=.04 ; \mathrm{RMSEA}=.06$. 
The results show that corporate hypocrisy negatively influences CSR belief and perceived reputation for the company. Hence the evidence supports H1 ( $\beta=-0.424, p<$ 0.001) and H2 $(\beta=-0.391, p<0.001)$. However, corporate hypocrisy did not influence consumers' attitudes toward the company. Therefore, the evidence did not support H3.

Moreover, we found that CSR belief positively influenced consumers’ attitudes toward the company. Thus, the evidence support H4 $(\beta=0.374, p<0.001)$. Finally, perceived corporate reputation positively influenced consumers' attitudes toward the company. Therefore, the evidence supported H5 $(\beta=0.188, p<0.05)$.

\section{Insert Figure 2 and Table 4 About Here}

\subsection{Mediating Effect}

Based on the criteria established by Baron and Kenny (1986), the results indicated that CSR belief mediated the relationship between corporate hypocrisy and consumers’ attitudes toward the beer company $(-0.246 ;-0.079)$. Hence, the evidence supports H6. Furthermore, the results show that corporate reputation mediated the relationship between corporate hypocrisy and consumers' attitudes (-0.189; -0.035) for the beer company. Therefore, the evidence supported H7.

In summary, both CSR belief and corporate reputation did mediate the relationships, between corporate hypocrisy and consumers' attitudes toward the company. Table 5 summarizes the results of the mediating effects.

\section{Insert Table 5 About Here}

\section{Discussion and Implications}

This research has implications for managers, social marketers, and public policy makers working in CSR. In regards to the direct effects, the results indicated that corporate hypocrisy significantly influenced CSR belief and perceived reputation for the company, but 
it did not significantly influence consumers' attitudes toward the company. The implication is that companies need to be transparent in their CSR campaigns. Certain companies that are currently under scrutiny by the public (e.g., soft drinks companies, fast food companies, beer companies, tobacco companies) need to be careful when launching CSR campaigns relating to their products (e.g., a soft drink company and an obesity campaign; a beer company and a drunk driving campaign), which consumers may perceive as covering up the consequences of their product and services. Unfortunately, there are no easy solutions for these types of companies but to innovate and create better products (e.g., low-calorie soft drinks, healthy fast food) and slowly to discontinue the products and services that harm society. A recent example is Coca Cola's effort to reduce the sugar in its product by replacing it with stevia plant extract (Stanford, 2015). Despite still seeming disingenuous, these small steps may work eventually as consumers respond positively to this type of behavior. Subsequently, these efforts may diminish consumer negative belief toward the company. Once companies can show genuine motivations for their CSR activities, consumers will eventually start supporting and believing in the brand again.

Moreover, the results show corporate hypocrisy did not significantly influence consumers' attitude toward the company. It is an indication that consumers deemed the beer company of acting hypocritically but their attitude remain unchanged toward the company. The non-significant result might be due to the nature of the company. Consumers may already be aware that these particular companies (e.g. beer, tobacco) often act hypocritically (Palazzo \& Richter 2005). Hence, their attitude toward these companies remains unchanged. Future research may compare and contrast consumers’ perception toward corporate hypocrisy of various industries in order to understand the effect of company hypocrisy on consumers' perception $^{1}$.

\footnotetext{
${ }^{1}$ We thank an anonymous reviewer for this feedback
} 
Furthermore, in regards to the mediating effect, both CSR belief and corporate reputation mediated the relationship between corporate hypocrisy and consumers' attitude toward the company. Consequently, for companies with good reputations, maintaining good reputations through CSR becomes critical. Engaging in CSR activities is an effective safeguard against potential crises such as consumer boycotts and negative press releases (Klein \& Dawar, 2004; Luo \& Bhattacharya, 2006; Weber, 2008). However, for companies with bad reputations, such as beer companies and tobacco companies, this situation creates a challenge for social and public policy makers working in this area. Consequently, when these companies (i.e., beer and tobacco companies) can improve their reputation through various activities such as CSR, their consumers will have more positive attitudes toward them irrespective of their products and services. In the case of tobacco companies, for example, consumers are ignoring the consequences of smoking (e.g., lung cancer) due to their CSR campaigns. Thus, consumers need to be aware of companies that may use CSR to redirect their attention to less urgent topics.

The results indicated that through CSR, the beer company may be able to shift the responsibility from the manufacturer to the consumer (i.e., drink responsibly). CSR has become an integral part the alcohol industry, and it portrays the major players as good citizens (Yoon \& Lam, 2013). There are two sides to the results of this study. First, from a public policy point of view, consumers need to be aware of the real motives of CSR campaigns by companies who often produce products with negative impacts on health (e.g., tobacco and alcohol) or the environment (e.g., oil). Second, from a company point of view, companies need to ensure the transparency and honesty of their CSR activities to reduce negative consumer attitudes.

Finally, the results indicated that CSR belief and perceived reputation significantly influences consumers' attitudes toward the company. Consequently, social marketers and 
public policy makers should consistently evaluate companies’ CSR motives, which will put pressure on those companies to minimize the negative impacts of their businesses on society. For example, regulators caught Volkswagen creating sophisticated software to avoid compliance with environmental regulations. It embedded a device in its diesel engines which could change performance and improve test results in the United States (Holten, 2015). Regulators found inconsistencies in Volkswagen's tests to measure carbon dioxide emission levels. In 2016, Volkswagen agreed to pay $\$ 14.7$ billion to settle this scandal (Isidore \& Goldman, 2016). Hence, with consistent monitoring, regulators can prevent cases like this, where the company deliberately sets out to design a tool to evade emission controls.

\section{Limitations and Future Research}

This study has several limitations. First, the study took place in Australia, which may limit its generalizability. Consumers in other developed countries and developing countries such as China, Indonesia, or India may respond differently to comparable CSR campaigns. CSR is not homogenous, but varies among countries (Blasco \& Zølner, 2010; Chapple \& Moon, 2005). For example, a study has shown that consumers in Indonesia have favorable attitudes toward CSR campaigns launched by tobacco companies (Arli, Rundle-Thiele, \& Lasmono, 2015). Future research may compare and contrast consumers’ perceptions of CSR between developed and developing countries to produce more generalizable results. Second, the study only tests consumers’ perceptions of one CSR campaign from one industry (i.e., beer).

Future research may extend to other sectors such as automotive, hotels, and finance. A more comprehensive analysis will produce a clearer strategy for social marketers and public policy makers to respond to the CSR campaigns various companies launch. Finally, future research may investigate how the relationships we have modeled may differ across various product 
categories. For example, CSR belief may be largely irrelevant to hedonic products such as beer and tobacco, but quite salient to utilitarian products such as energy ${ }^{2}$

\footnotetext{
${ }^{2}$ We thank an anonymous reviewer for this feedback.
} 


\section{References}

Albinger, H. S., Freeman, S. J. 2000.Corporate social performance and attractiveness as an employer to different job seeking populations. Journal of Business Ethics, 28(3), 243-253.

Alhouti, S., Johnson, C. M., Holloway, B. B. 2016. Corporate social responsibility authenticity: investigating its antecedents and outcomes. Journal of Business Research, 69(3), 1242-1249.

Anderson, J. C., Gerbing, D. W. 1988. Structural equation modeling in practice: a review and recommended two-step approach. Psychological Bulletin, 103(3), 411.

Argenti, P. A., Druckenmiller, B. 2004.Reputation and the corporate brand. Corporate Reputation Review, 6(4), 368-374.

Arli, D., Cadeaux, J. 2014. Drivers of corporate community involvement and challenges in measuring its impact. Social Responsibility Journal, 10(1), 161-183.

Arli, D. I., Lasmono, H. K. 2010. Consumers' perception of corporate social responsibility in a developing country. International Journal of Consumer Studies, 34(1), 46-51.

Arli, D., Rundle-Thiele, S., Lasmono, H. 2015. Consumers’ evaluation toward tobacco companies: implications for social marketing. Marketing Intelligence and Planning, 33(3), 276-291.

Aupperle, K. E., Carroll, A. B., Hatfield, J. D. 1985. An empirical examination of the relationship between corporate social responsibility and profitability. Academy of Management Journal, 28(2), 446-463.

Baggott, R. 2006. Alcohol strategy and the drinks industry, Joseph Rowntree Foundation, available at: www.drugslibrary.stir.ac.uk/documents/alcoholindustry.pdf (accessed September 2016).

Bagozzi, R. P., Yi, Y. 2012. Specification, evaluation, and interpretation of structural equation models. Journal of the Academy of Marketing Science,40(1), 8-34.

Balmer, J. M., Fukukawa, K., Gray, E. R. 2007. The nature and management of ethical corporate identity: A commentary on corporate identity, corporate social responsibility and ethics. Journal of Business Ethics, 76(1), 7-15.

Baron, R. M., Kenny, D. A. (1986). The moderator-mediator variable distinction in social psychological research: Conceptual, strategic, and statistical considerations. Journal of Personality and Social Psychology, 51, 1173-1182.

Becker-Olsen, K. L., Cudmore, B. A., Hill, R. P. 2006. The impact of perceived corporate social responsibility on consumer behavior. Journal of Business Research, 59(1), 46-53.

Bendapudi, N., Singh, S. N., Bendapudi, V. 1996. Enhancing helping behavior: an integrative framework for promotion planning. Journal of Marketing, 60(3), 33-49. 
Bhattacharya, C. B., Sen, S. 2003. Consumer-company identification: A framework for understanding consumers' relationships with companies. Journal of Marketing, 67(2), 76-88.

Blasco, M., Zølner, M. 2010. Corporate social responsibility in Mexico and France exploring the role of normative institutions. Business and Society, 49(2), 216-251.

Boulstridge, E., Carrigan, M. 2000. Do consumers really care about corporate responsibility? Highlighting the attitude-behaviour gap. Journal of Communication Management, 4(4), 355368.

Brown, T. J., Dacin, P. A. 1997. The company and the product: corporate associations and consumer product responses. Journal of Marketing, 61(1), 68-84.

Campbell, M. C. 1995. When attention-getting advertising tactics elicit consumer inferences of manipulative intent: the importance of balancing benefits and investments. Journal of Consumer Psychology, 4(3), 225-254.

Carroll, A. B. 1979. A three-dimensional conceptual model of corporate performance. Academy of Management Review, 4(4), 497-505.

Carroll, A. B. 1991. The pyramid of corporate social responsibility: toward the moral management of organizational stakeholders. Business Horizons, 34(4), 39-48.

Chapple, W., Moon, J. 2005. Corporate social responsibility (CSR) in asia a seven-country study of CSR web site reporting. Business and Society, 44(4), 415-441.

Chylinski, M., Chu, A. 2010. Consumer cynicism: antecedents and consequences. European Journal of Marketing, 44(6), 796-837.

Crespo, A. H., del Bosque, I. R. 2005. Influence of corporate social responsibility on loyalty and valuation of services. Journal of Business Ethics, 61(4), 369-385.

Creyer, E. H., Ross Jr, W. T. 1996.The impact of corporate behavior on perceived product value. Marketing letters, 7(2), 173-185.

Crowther, D., Rayman-Bacchus, L. 2004.Perspectives on corporate social responsibility. Hampshire, England: Gower Publishing, Ltd.

Dahl, R. A. (1972).A prelude to corporate reform. Business and Society Review, 1, 17-23.

Darke, P. R., Ritchie, R. J. 2007. The defensive consumer: Advertising deception, defensive processing, and distrust. Journal of Marketing Research, 44(1), 114-127.

Deshpande, S. P. 1996. The impact of ethical climate types on facets of job satisfaction: an empirical investigation. Journal of Business Ethics, 15(6), 655-660.

Devinney, T. M., Auger, P., Eckhardt, G., Birtchnell, T. 2006. The other CSR. Stanford Social Innovation Review, 4(3), 30-37. 
Du, S., Bhattacharya, C. B., Sen, S. 2007. Reaping relational rewards from corporate social responsibility: The role of competitive positioning. International Journal of Research in Marketing, 24(3), 224-241.

Ellen, P. S., Mohr, L. A., Webb, D. J. 2000. Charitable programs and the retailer: do they mix?. Journal of Retailing, 76(3), 393-406.

Fatma, M., Rahman, Z. 2015.Consumer perspective on CSR literature review and future research agenda. Management Research Review, 38(2), 195-216.

Forbes. 2015. The companies with the best CSR reputations in the world. Source: http://www.forbes.com/sites/susanadams/2015/09/17/the-companies-with-the-best-csrreputations-in-the-world/\#4dc1265e762c.

Fornell, C., Larcker, D. F. 1981. Structural equation models with unobservable variables and measurement error: Algebra and statistics. Journal of Marketing Research, 8, 382-388

Fombrun, C. J. 1996. Reputation: Realizing Value from the Corporate Image (Harvard Business School Press, Cambridge, MA).

Forehand, M. R. 2000.Extending over justification: the effect of perceived reward-giver intention on response to rewards. Journal of Applied Psychology, 85(6), 919.

Friedman, M. 1970. The social responsibility of business is to increase its profits. New York, 122-124.

Gupta, S., Pirsch, J. 2008. The influence of a retailer's corporate social responsibility program on re-conceptualizing store image. Journal of Retailing and Consumer Services, 15(6), 516526.

Hallowell, R. 1996. The relationships of customer satisfaction, customer loyalty, and profitability: an empirical study. International Journal of Service Industry Management, 7(4), 27-42.

Heider, F. 1944. Social perception and phenomenal causality. Psychological Review, 51(6), 358.

Herbig, P., Milewicz, J. 1995.The relationship of reputation and credibility to brand success. Journal of Consumer Marketing, 12(4), 5-10.

Holten, R. (2015). Volkswagen: the scandal explained. Source: http://www.bbc.com/news/business-34324772. (accessed: 10 February 2017).

Homer, P. M. 1995. Ad size as an indicator of perceived advertising costs and effort: The effects on memory and perceptions. Journal of Advertising, 24(4), 1-12.

Hur, W. M., Kim, H., Woo, J. 2014. How csr leads to corporate brand equity: mediating mechanisms of corporate brand credibility and reputation. Journal of Business Ethics, 125(1), 75-86. 
Illia, L., Zyglidopoulos, S. C., Romenti, S., Rodríguez-Cánovas, B., del Valle Brena, A. G. 2013. Communicating corporate social responsibility to a cynical public. MIT Sloan Management Review, 54(3), 2.

Isidore, C. Goldman, D. (2016). Volkswagen agrees to record \$14.7 billion settlement over emissions cheating. Source: http://money.cnn.com/2016/06/28/news/companies/volkswagenfine/. (accessed: 12 February 2017).

Jensen, M. C. 2001. Value maximization, stakeholder theory, and the corporate objective function. Journal of Applied Corporate Finance, 14(3), 8-21.

Jones, B., Bowd, R., and Tench, R. 2009. Corporate irresponsibility and corporate social responsibility: competing realities. Social Responsibility Journal, 5(3), 300-310.

Jones, P., Hillier, D., Comfort, D. 2013. The leading spirits and beer companies and corporate social responsibility. Corporate Governance: The International Journal of Business in Society, 13(3), 249-260.

Karem Kolkailah, S., Abou Aish, E., El-Bassiouny, N. 2012. The impact of corporate social responsibility initiatives on consumers' behavioural intentions in the Egyptian market. International Journal of Consumer Studies, 36(4), 369-384.

Kelley, H. H. 1967. Attribution theory in social psychology. In Nebraska symposium on motivation.University of Nebraska Press.

Klein, J., Dawar, N. 2004. Corporate social responsibility and consumers' attributions and brand evaluations in a product-harm crisis. International Journal of Research in Marketing, 21(3), 203-217.

Kubacki, K., Siemieniako, D., Rundle-Thiele, S. 2011. College binge drinking: a new approach. Journal of Consumer Marketing, 28(3), 225-233.

Lau, R. S., Cheung, G. W. 2010. Estimating and comparing specific mediation effects in complex latent variable models. Organizational Research Methods, 1094428110391673.

Lee, M. S., Motion, J., Conroy, D. 2009. Anti-consumption and brand avoidance. Journal of Business Research, 62(2), 169-180.

Leonidou, C. N., Skarmeas, D. 2015. Gray Shades of Green: Causes and Consequences of Green Skepticism. Journal of Business Ethics, 1-15. doi:10.1007/s10551-015-2829-4

Lichtenstein, D. R., Drumwright, M. E., Braig, B. M. 2004. The effect of corporate social responsibility on customer donations to corporate-supported nonprofits. Journal of Marketing, 68(4), 16-32.

Lii, Y. S., Lee, M. 2012. Doing right leads to doing well: when the type of csr and reputation interact to affect consumer evaluations of the firm. Journal of Business Ethics, 105(1), 69-81.

Lindenmeier, J., Schleer, C., Pricl, D. 2012. Consumer outrage: Emotional reactions to unethical corporate behavior. Journal of Business Research, 65(9), 1364-1373. 
Luo, X., Bhattacharya, C. B. 2006.Corporate social responsibility, customer satisfaction, and market value. Journal of Marketing, 70(4), 1-18.

Maignan, I., Ferrell, O.C., Hult, G.T. 1999. Corporate citizenship: cultural antecedents and business benefits. Journal of Academy of Marketing Science, 27(4), 455 - 469.

Matten, D., Crane, A., Chapple, W. 2003. Behind the mask: Revealing the true face of corporate citizenship. Journal of Business Ethics, 45(1-2), 109-120.

McIntosh, B. 2015. Entrepreneurship-A new dawn. The Journal of Strategy, Operations and Economics, 1(1).

Mohr, L. A., Eroğlu, D., Ellen, P. S. 1998. The development and testing of a measure of skepticism toward environmental claims in marketers' communications. Journal of Consumer Affairs, 32(1), 30-55.

Mohr, L. A., Webb, D. J. 2005.The effects of corporate social responsibility and price on consumer responses. Journal of Consumer Affairs, 39(1), 121-147.

Murray, K. B., Vogel, C. M. 1997. Using a hierarchy-of-effects approach to gauge the effectiveness of corporate social responsibility to generate goodwill toward the firm: Financial versus nonfinancial impacts. Journal of Business Research, 38(2), 141-159.

Nguyen, N., Leblanc, G. 2001.Corporate image and corporate reputation in customers' retention decisions in services. Journal of Retailing and Consumer Services, 8(4), 227-236.

Oppewal, H., Alexander, A., Sullivan, P. 2006. Consumer perceptions of corporate social responsibility in town shopping centres and their influence on shopping evaluations. Journal of Retailing and Consumer Services, 13(4), 261-274.

Orlitzky, M., Schmidt, F. L., Rynes, S. L. 2003. Corporate social and financial performance: A meta-analysis. Organization Studies, 24(3), 403-441.

Palazzo, G., Richter, U. (2005). CSR business as usual? The case of the tobacco industry. Journal of Business Ethics, 61(4), 387-401.

Pan, Y., Zinkhan, G. M. 2006. Determinants of retail patronage: a meta-analytical perspective. Journal of Retailing, 82(3), 229-243.

Parsa, H.G., Kenneth, R.L., Putrevu, S., Kreeger, J., 2015. Corporate social and environmental responsibility in services: will consumers pay for it? Journal of Retailing and. Consumer Services, 22, 250-260.

Podnar, K., Golob, U. 2007. CSR expectations: the focus of corporate marketing. Corporate communications: An international Journal, 12(4), 326-340.

Preacher, K. J., Hayes, A. F. 2008. Asymptotic and resampling strategies for assessing and comparing indirect effects in multiple mediator models. Behavior Research Methods, 40(3), 879-891. 
Quarter, J. 2000.Beyond the bottom line: Socially innovative business owners. Greenwood Publishing Group.

Roberts, P. W., Dowling, G. R. 2002.Corporate reputation and sustained superior financial performance. Strategic Management Journal, 23(12), 1077-1093.

Room, R., Babor, T., Rehm, J. 2005. Alcohol and public health. The Lancet, 365(9458), 519530 .

Rundle-Thiele, S.R., Russell-Bennett, R., Leo, C. Dietrich, T. 2013. Moderating teen drinking: combining social marketing and education. Health Education, 113

(5), 392-406.

Sen, S., Bhattacharya, C. B. 2001. Does doing good always lead to doing better? consumer reactions to corporate social responsibility. Journal of Marketing Research, 38(2), 225-243.

Skarmeas, D., Leonidou, C. N. 2013. When consumers doubt, watch out! the role of csr skepticism. Journal of Business Research, 66(10), 1831-1838.

Sprinkle, G. B., Maines, L. A. 2010.The benefits and costs of corporate social responsibility. Business Horizons, 53(5), 445-453.

Stanaland, A. J., Lwin, M. O., Murphy, P. E. 2011.Consumer perceptions of the antecedents and consequences of corporate social responsibility. Journal of Business Ethics, 102(1), 4755.

Stanford, D. 2015. Scientists are racing to build a better diet soda. Source: http://www.bloomberg.com/news/articles/2015-03-19/coke-pepsi-seek-diet-soda-s-perfectsweetener. (accessed: 20 July 2016).

Sweetin, V. H., Knowles, L. L., Summey, J. H., McQueen, K. S. 2013. Willingness-topunish the corporate brand for corporate social irresponsibility. Journal of Business Research, 66(10), 1822-1830.

Szabados, B., Soifer, E. 2004. Hypocrisy: ethical investigations. Ontario: Broadview Press.

Szykman, L. R., Bloom, P. N., Blazing J. (2004). Does corporate sponsor- \$hip of a sociallyoriented message make a difference? An investigation of the effects of sponsorship identity on responses to an anti-drinking and driving message. Journal of Consumer Psychology, 14, 13-20.

Valentine, S., Fleischman, G. 2008. Ethics programs, perceived corporate social responsibility and job satisfaction. Journal of Business Ethics, 77(2), 159-172.

Vanhamme, J., Grobben, B. 2009. “Too good to be true!”.The effectiveness of CSR history in countering negative publicity. Journal of Business Ethics, 85(2), 273-283.

Waddock, S. 2004. Parallel universes: Companies, academics, and the progress of corporate citizenship. Business and Society Review, 109(1), 5-42. 
Wagner, T., Lutz, R. J., Weitz, B. A. 2009. Corporate hypocrisy: overcoming the threat of inconsistent corporate social responsibility perceptions. Journal of Marketing, 73(6), 77-91.

Wan, L. C., Poon, P. S., Yu, C. 2016. Consumer reactions to corporate social responsibility brands: the role of face concern. Journal of Consumer Marketing, 33(1), 52-60.

Webb, D. J., Mohr, L. A. 1998. A typology of consumer responses to cause-related marketing: from skeptics to socially concerned. Journal of Public Policy and Marketing, 226238.

Weber, M. 2008. The business case for corporate social responsibility: A company-level measurement approach for CSR. European Management Journal, 26(4), 247-261.

Wechsler, H., Lee, J. E., Kuo, M., Lee, H. 2000. College binge drinking in the 1990s: A continuing problem results of the Harvard School of Public Health 1999 College Alcohol Study. Journal of American College Health, 48(5), 199-210.

Weiner, B. 1985. An attributional theory of achievement motivation and emotion. Psychological Review, 92(4), 548.

Weiss, A. M., Anderson, E., MacInnis, D. J. 1999. Reputation management as a motivation for sales structure decisions. Journal of Marketing, 63(4), 74-89.

Yoon, E., Guffey, H. J., Kijewski, V. 1993. The effects of information and company reputation on intentions to buy a business service. Journal of Business Research, 27(3), 215228.

Yoon, S., Lam, T. H. 2013. The illusion of righteousness: corporate social responsibility practices of the alcohol industry. BMC Public Health, 13(1), 630.

Yoon, Y., Gürhan-Canli, Z., Schwarz, N. 2006.The effect of corporate social responsibility (CSR) activities on companies with bad reputations. Journal of Consumer Psychology, 16(4), 377-390.

Zhao, X., Lynch, J. G., Chen, Q. 2010. Reconsidering Baron and Kenny: Myths and truths about mediation analysis. Journal of Consumer Research, 37(2), 197-206. 


\section{Appendix}

Figure 1.Conceptual Model

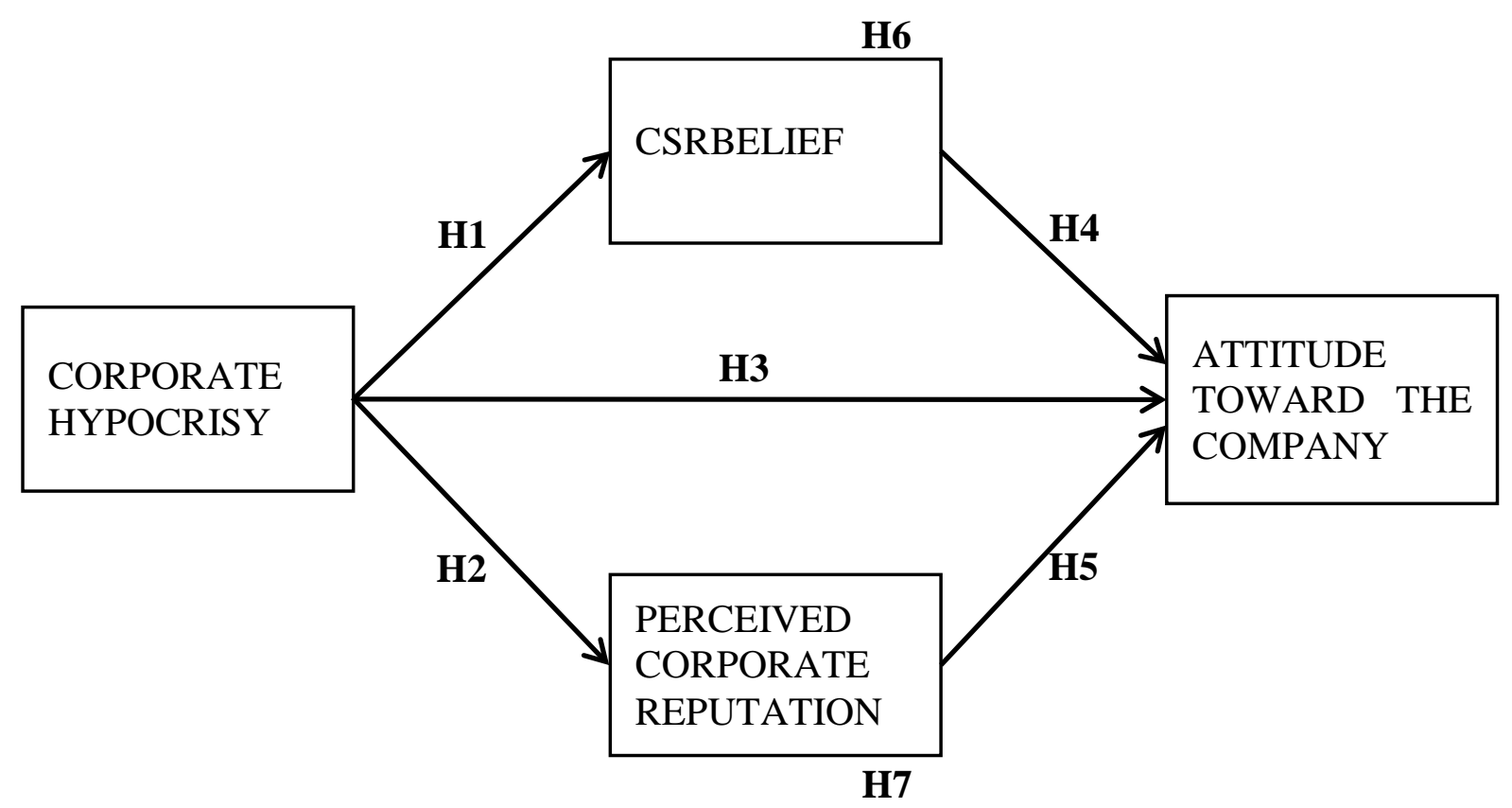

Figure 2. Conceptual Model (Hypothesis Results)

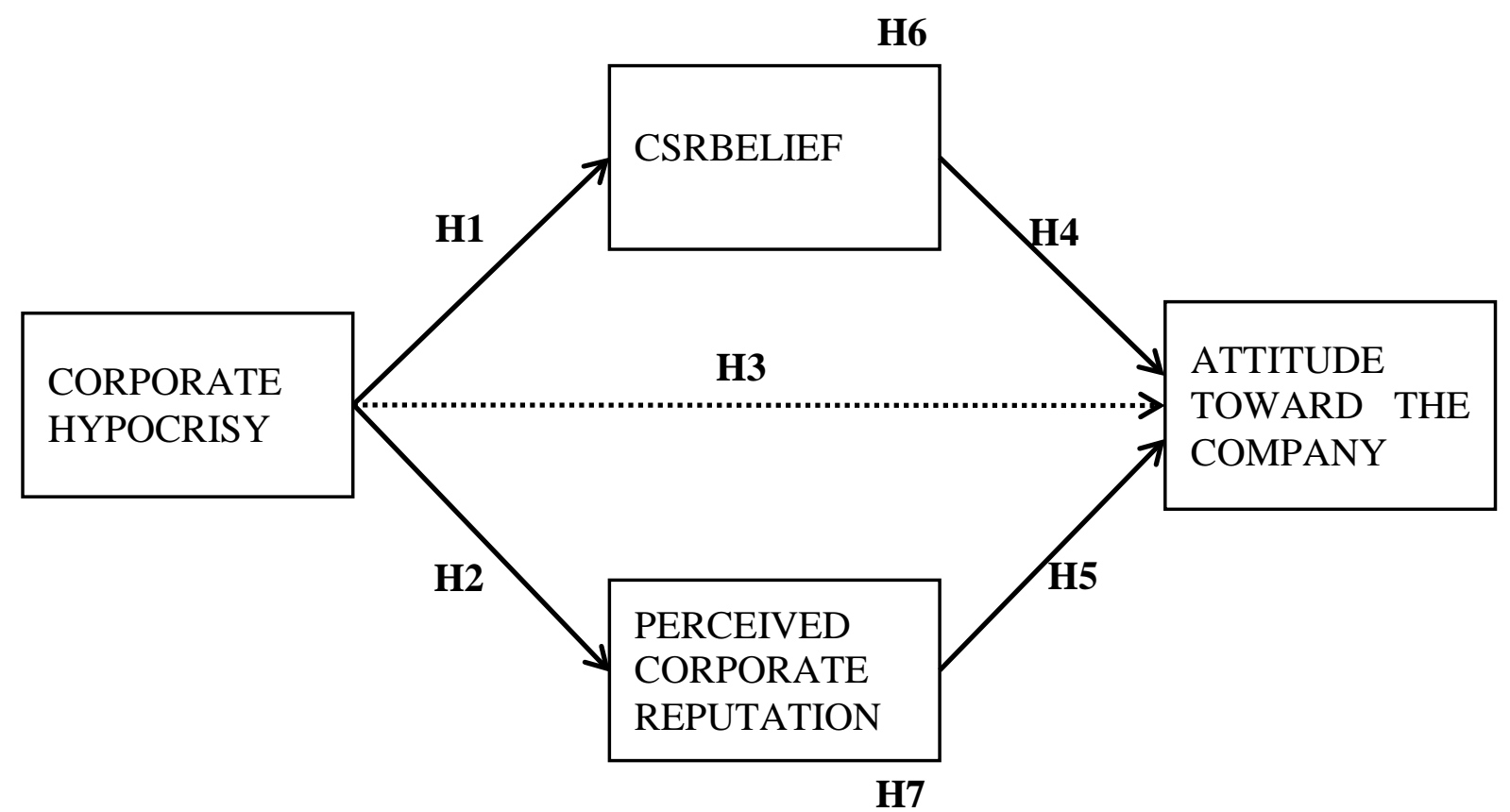

Note: $\rightarrow$ Sig $(p<0.05)$; ---> No Sig $(p>0.05)$ 
Figure 2. Anheuser-Busch CSR Banner

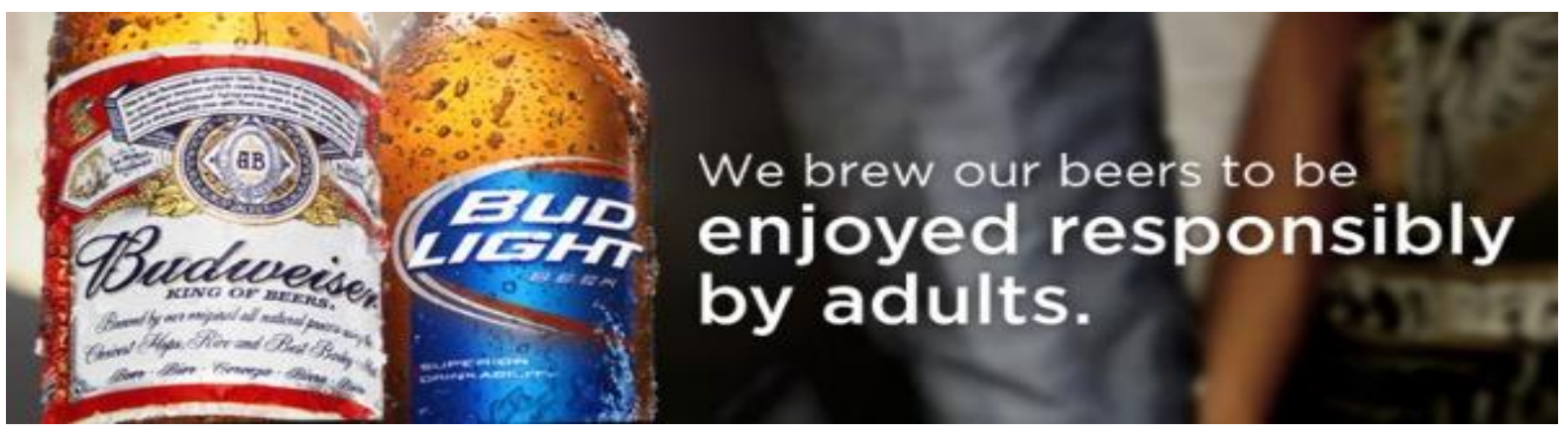


Table 1. Respondent demographic profile

\begin{tabular}{|l|c|c|}
\hline \multirow{2}{*}{ Demographic Profile } & \multicolumn{2}{|c|}{$\mathrm{n}=518$} \\
\cline { 2 - 3 } & $\mathrm{n}$ & $\%$ \\
\hline Gender & $\mathbf{5 1 8}$ & \\
Male & 258 & $49.9 \%$ \\
Female & 259 & $50.1 \%$ \\
\hline Age & $\mathbf{5 1 7}$ & \\
& & \\
$18-24$ & 269 & $52.0 \%$ \\
$25-34$ & 85 & $16.4 \%$ \\
$35-44$ & 30 & $5.8 \%$ \\
$45-54$ & 82 & $15.9 \%$ \\
$55-64$ & 42 & $8.1 \%$ \\
65 and above & 9 & $1.7 \%$ \\
\hline Education & $\mathbf{5 1 3}$ & \\
Primary (elementary) & & \\
Secondary (high school) & 17 & $3.3 \%$ \\
University & 219 & $42.7 \%$ \\
College & 178 & $34.7 \%$ \\
Postgraduate & 51 & $9.9 \%$ \\
Other & 38 & $7.5 \%$ \\
\hline Income (Individual) & 10 & $1.9 \%$ \\
Less than \$20,000 & $\mathbf{5 0 8}$ & \\
\$21,000 - \$40,000 & & \\
\$41,000 - \$60,000 & 186 & $36.6 \%$ \\
\$61,000 - \$81,000 & 104 & $20.5 \%$ \\
\$81,000 - \$100,000 & 100 & $19.7 \%$ \\
Above \$100,000 & 49 & $9.6 \%$ \\
\hline Marital Status & 31 & $6.1 \%$ \\
Single & 38 & $7.5 \%$ \\
Married & $\mathbf{5 1 4}$ & \\
Divorced & 277 & $53.9 \%$ \\
Widowed & 138 & $26.8 \%$ \\
Other & 33 & $6.4 \%$ \\
Note & 10 & $1.9 \%$ \\
& 56 & $10.9 \%$ \\
\hline
\end{tabular}

Notes: Inconsistency in sample sizes is attributed to unfilled respondent data. 
Table 2.Confirmatory Factor Analysis (Cont)

\begin{tabular}{|c|c|c|c|c|}
\hline \multirow[t]{2}{*}{ Factor } & \multirow[t]{2}{*}{ Item } & \multirow{2}{*}{$\begin{array}{l}\text { Convergent Validity } \\
\text { Factor Loading } \\
\end{array}$} & \multicolumn{2}{|l|}{ Reliability } \\
\hline & & & CR & AVE \\
\hline CSR Belief (Maignan, 2001; Crespo and Bosque, 2005) & & & 0.86 & 0.67 \\
\hline ...is a socially responsible company. & CSRB01 & 0.81 & & \\
\hline ...concerned to improve the well-being of society. & CSRB02 & 0.81 & & \\
\hline ...follows high ethical standards. & CSRB03 & 0.83 & & \\
\hline 1=Strongly Disagree; 5=Strongly Agree & & & & \\
\hline Perceived Corporate Reputation (Brown, 1995; Ganesan, 1994) & & & 0.87 & 0.59 \\
\hline The company has a reputation for being honest. & CR01 & 0.80 & & \\
\hline The company has a reputation for being reliable. & CR02 & 0.75 & & \\
\hline The company has a reputation for being trustworthy. & CR03 & 0.85 & & \\
\hline $\begin{array}{l}\text { The company is committed to well-defined ethics principles. } \\
1=\text { Strongly Disagree; } 5=\text { Strongly Agree }\end{array}$ & CR04 & 0.66 & & \\
\hline Corporate Hypocrisy (Wagner et al. 2009) & & & 0.85 & 0.65 \\
\hline ....acts hypocritically. & CH01 & 0.70 & & \\
\hline What ... says and does are two different things. & CH02 & 0.91 & & \\
\hline ...pretends to be something that is not. & $\mathrm{CH} 03$ & 0.80 & & \\
\hline 1=Strongly Disagree; $5=$ Strongly Agree & & & & \\
\hline Attitude (Homer, 1985) & & & 0.94 & 0.80 \\
\hline Unfavorable - Favorable & OF01 & 0.83 & & \\
\hline Bad - Good & OF02 & 0.92 & & \\
\hline Unpleasant - Pleasant & OF03 & 0.92 & & \\
\hline Negative - Positive & OF04 & 0.91 & & \\
\hline
\end{tabular}

Notes: CR Composite Reliability, AVE Average Variance Extracted 
Table 3. Discriminant Validity

\begin{tabular}{lllll}
\hline & 1 & 2 & 3 & 4 \\
\hline 1. CSR Belief & $\mathbf{0 . 6 7}$ & 0.307 & 0.130 & 0.229 \\
2. CSR Reputation & $0.555^{* *}$ & $\mathbf{0 . 5 9}$ & 0.106 & 0.177 \\
3. Corporate Hypocrisy & $-0.361^{* *}$ & $-0.325^{* *}$ & $\mathbf{0 . 6 5}$ & 0.151 \\
5. Attitude & $0.479^{* *}$ & $0.421^{* *}$ & $-0.297^{* *}$ & $\mathbf{0 . 8 0}$ \\
\hline Mean & 3.15 & 3.21 & 2.92 & 3.26 \\
Std Dev & 0.76 & 0.55 & 0.71 & 0.92 \\
\hline
\end{tabular}

Notes: Values below the diagonal are bivariate correlations between the constructs, bold diagonal elements represents the Average Variance Extracted (AVEs) for the relevant construct; Values above the diagonal represent squared correlations; Values below the diagonal represent correlations

Table 4.Structural Model Results

\begin{tabular}{|c|c|c|c|c|}
\hline Hypothesis & Path & Path Coefficient & p-value & Result \\
\hline H3 & Corporate Hypocrisy $\rightarrow$ Attitude & -0.087 & 0.067 & Not Supported \\
\hline $\mathrm{H} 4$ & CSR Beliefs $\rightarrow$ Attitude & 0.374 & 0.000 & Supported \\
\hline
\end{tabular}

Note: Fit Statistics: $\mathrm{x} 2 / \mathrm{df}(71)=205.244$; CFI=0.97; TLI=0.96; NNFI=.96; RMSEA=0.061; SRMR $=.036$

Table 5. Mediating Effect

\begin{tabular}{|l|l|l|l|l|l|l|}
\hline Hypothesis & Relationship & Direct Effect & Indirect Effect & Lower & Upper & Results \\
\hline H6 & Hypocrisy $\rightarrow$ CSR Belief $\rightarrow$ Attitude & $-0.152(\mathrm{~ns})$ & $-0.141^{*}$ & -0.246 & -0.079 & Supported \\
\hline H7 & Hypocrisy $\rightarrow$ Reputation $\rightarrow$ Attitude & $-0.175(\mathrm{~ns})$ & $-0.076^{*}$ & -0.012 & -0.045 & Supported \\
\hline
\end{tabular}

Note: $* * p<0.001 ; * p<0.05$; ns $=$ not significant; 0 does not occur within the lower and upper limit of the $95 \%$ confidence interval. CSR belief did not significantly related to Attitude. Hence, mediation effect cannot be established (Baron and Kenny 1986). 
-- END OF MANUSCRIPT -- 